DOI: https://doi.org/10.24127/ajpm.v10i1.3179

\title{
ANALISIS KEMAMPUAN KOMUNIKASI MATEMATIKA SISWA MELALUI PENGGUNAAN PROJECT-BASED LEARNING TERINTEGRASI STEM
}

\author{
Sukma Mawaddah ${ }^{*}$, Ali Mahmudi ${ }^{2}$ \\ ${ }^{1 *, 2}$ Universitas Negeri Yogyakarta, Sleman, Indonesia \\ ${ }^{*}$ Corresponding author. Depok, 55281, Sleman, Indonesia. \\ E-mail: $\quad \frac{\text { sukma0047pasca.2018@ student.uny.ac.id }}{\text { alimahmudi@uny.ac.id }^{2)}}$
}

Received 20 October 2020; Received in revised form 24 November 2020; Accepted 29 March 2021

\begin{abstract}
Abstrak
Tujuan penelitian ini adalah untuk mendeskripsikan kemampuan komunikasi matematika siswa dalam pembelajaran model Project-Based Learning menggunakan pendekatan Science, Technology, Engineering, and Mathematics (STEM). Penelitian ini menggunakan pendekatan kualitatif dengan metode deskriptif. Penelitian dilakukan pada siswa kelas 5 Sekolah Dasar Negeri Puren, Daerah Istimewa Yogyakarta. Data dikumpulkan dengan teknik tes, wawancara, dan dokumentasi. Instrumen pengumpulan data berupa tes kemampuan komunikasi matematika. Hasil penelitian menunjukkan bahwa penerapan pembelajaran Project-Based Learning terintegrasi STEM dapat meningkatkan kemampuan komunikasi matematika siswa dalam tiga aspek yang diteliti, yaitu menghubungkan ide matematis berdasarkan gambar maupun representasi matematika yang relevan, menggunakan gambar maupun representasi matematis yang sesuai untuk menyampaikan ide matematis, dan menggunakan bahasa matematika untuk menyelesaikan permasalahan matematis. Selain itu, sebanyak 78,125\% siswa termasuk dalam ketegori tuntas berdasarkan KKM yang digunakan pada kelas penelitian.
\end{abstract}

Kata kunci: Komunikasi matematika; project-based learning; STEM.

\begin{abstract}
The purpose of this study was to describe students' mathematical communication skills in the projectbased learning model using the Science, Technology, Engineering, and Mathematics (STEM) approach. This research uses a qualitative approach with descriptive methods. The research was conducted on 5th grade students of Puren State Elementary School, Yogyakarta Special Region. Data were collected by means of tests, interviews, and documentation. The data collection instrument was a test of mathematical communication skills. The results showed that the implementation of the STEM integrated Project-Based Learning model could improve students' mathematical communication skills in the three aspects studied, namely connecting mathematical ideas based on images and relevant mathematical representations, using images and appropriate mathematical representations to convey mathematical ideas, and using mathematical language to solve mathematical problems. In addition, as many as $78.125 \%$ of students were included in the complete category based on the minimum completeness criteria used in the research class.
\end{abstract}

Keywords: Mathematical communication; project-based learning; STEM.

This is an open access article under the Creative Commons Attribution 4.0 International License

\section{PENDAHULUAN}

Pembelajaran yang marak dilakukan saat ini adalah pembelajaran yang berorientasi pada kemampuan abad ke-21. Kemampuan tersebut meliputi kreativitas dan inovasi, berpikir kritis dan pemecahan masalah, komunikasi, dan kolaborasi (Nesri \& Kristanto, 2020). Kemampuan komunikasi adalah salah satu dari empat kemampuan abad ke-21 yang penting 
untuk dimiliki setiap siswa, termasuk dalam pembelajaran matematika.

Kemampuan komunikasi dalam pembelajaran matematika atau kemampuan komunikasi matematika adalah aspek esensial dari pembelajaran matematika (NCTM, 2000). Komunikasi matematika adalah kemampuan untuk menyampaikan informasi menggunakan bahasa lisan atau tertulis tentang sifat/konsep matematis (Valle \& Barbosa, 2017).

Kemampuan komunikasi matematika dapat dilihat dari bagaimana siswa menghubungkan kasus dengan model matematika dan menjelaskan penyelesaiannya menggunakan bahasa yang efektif (Kleden, Kusumah, \& Sumarmo, 2015). Kemampuan komunikasi matematika juga dapat dilihat dari bagaimana siswa menyampaikan ide matematis melalui representasi kata, gambar, angka, simbol/notasi dengan benar (Walle, Karp, \& Wiliam, 2010; Kongthip, Inprasitha, Pattanajak, \& Inprasitha: 2012).

Kemampuan komunikasi matematika siswa sekolah dasar masih tergolong rendah dalam aspek menulis matematis, memahami ide matematika dalam konteks tertentu, representasi matematis, mengajukan pertanyaan matematika, dan menyusun kesimpulan matematis (Liestarie \& Karlimah, 2017; Noviarny, Murtono, \& Ulya, 2018). Kondisi di lapangan juga menunjukkan siswa belum mampu menghubungkan ide matematis dalam konteks nyata ke dalam model penyelesaian masalah matematis, sehingga jawaban yang diberikan oleh siswa tidak tepat. Siswa juga seringkali melakukan kesalahan dalam menulis notasi/simbol. Kesalahan dalam intepretasi matematika adalah akibat dari rendahnya kemampuan komunikasi matematis (Zetriuslita \& Jarnawi, 2018).
Kemampuan komunikasi matematika dapat dikembangkan melalui penggunaan konteks real yang dikemas dalam aktivitas belajar berbasis proyek (Ambarwati, Dwijanto, \& Hendikawati, 2015). Konteks real tersebut dapat berupa masalah yag diberikan kepada siswa untuk diselesaikan secara bersama (Alhaddad, Kusumah, Sabandar, \& Dahlan, 2015), sehingga proses penyelesaian masalah dalam proyek tersebut melatih siswa untuk berinteraksi, memahami informasi, dan mengomunikasikan pedekatan/gagasan matematis. Salah satunya adalah pembelajaran model Project-Based Learnig (PjBL) menggunakan pendekatan Science, Technology, Engineering, and Mathematics (STEM). Model PjBL menggunakan pendekatan STEM terdiri dari 5 langkah pembelajaran, yaitu reflection, research, discovery, dan communication (Laboy-Rush (2010). Lima langkah tersebut memberi banyak kesempatan kepada siswa aktif dalam penggunaan daya kognitif, melakukan diskusi, menyampaikan ide, dan latihan menyelesaikan permasalahan autentik (Aguilar, 2016).

Model PjBL menggunakan pendekatan STEM berpengaruh signifikan terhadap peningkatan kemampuan komunikasi siswa terutama dalam menyampaikan ide melalui kosa kata matematis seperti menyatakan panjang, luas, variabel, teorema, atau bahasa matematika lainnya (Bicer, Boedeker, Capraro, \& Capraro, 2015). Penerapan model PjBL menggunakan pendekatan STEM juga mampu meningkatkan kemampuan komunikasi matematika siswa terutama untuk menguraikan ide matematis dalam bentuk pemecahan masalah matematis yang runtut (Chalim, Mariani, \& Wijayanti, 2019). 
DOI: https://doi.org/10.24127/ajpm.v10i1.3179

Berdasarkan deskripsi tersebut, maka dipilij model Project-Based Learning menggunakan pendekatan STEM untuk diimplementasikan ke dalam pembelajaran matematika kelas 5 sekolah dasar dengan tujuan untuk meningkatkan kemampuan komunikasi matematika siswa.

\section{METODE PENELITIAN}

Penelitian ini adalah penelitian deskriptif dengan tujuan untuk mendeskripsikan peningkatan kemampuan komunikasi matematika siswa yang diberikan pembelajaran model Project-Based Learning menggunakan pendekatan STEM. Penelitian dilakukan selama Februari 2020 sampai dengan Juni 2020 di SDN Puren, Depok, Sleman, Daerah Istimewa Yogyakarta.

Fokus utama penelitian adalah pada kemampuan komunikasi matematis tertulis siswa dalam menyelesaikan permasalahan matematis, namun untuk mendukung deskripsi penelitian maka peneliti juga mengamati proses komunikasi lisan antar siswa dalam kelompok dan interaksi siswa dengan guru. Teknik tes adalah sebagai teknik utama untuk mengetahui kemampuan komunikasi matematika secara tertulis, teknik wawancara terbuka (tidak terstruktur) terhadap siswa dan guru, dan teknik dokumentasi. Instrumen yang digunakan adalah tes kemampuan komunikasi matematika, yaitu sebanyak 5 soal uraian materi geometri volume kubus dan balok. Wawancara terbuka untuk mengetahui pemahaman siswa terhadap konsep volume kubus dan balok. Wawancara terbuka kepada guru adalah untuk mengetahui sejauhmana siswa memahami materi yang disampaikan di kelas. Dokumentasi berupa penilaian dan telaah dokumen hasil pekerjaan siswa baik pada pre-test maupun post-test kemampuan komunikasi matematika.

Partisipan dalam penelitian ini adalah 32 orang siswa kelas 5 sekolah dasar dan seorang guru kelas 5 yang bertugas di kelas tersebut. Tes kemampuan kognitif dan observasi dilakukan secara klasikal, namun wawancara hanya dipilih 5 orang siswa yang mewakili untuk dimintai konfirmasi terhadap komunikasi matematika secara lisan, kelima siswa tersebut dikodekan dengan S01, S02, S03, S04, dan S05.

Analisis data dilakukan dengan model Miles \& Hubberman, yaitu pengumpulan data, kondensasi data, penyajian data, dan verifikasi yang dilakukan secara siklis (Milles, Hubberman, \& Saldana, 2014). Untuk memastikan keabsahan data yang terkumpul, peneliti menggunakan triangulasi teknik dan subjek. Triangulasi teknik dilakukan dengan mengecek data dari sumber yang sama dengan cara yang berbeda, dalam hal ini peneliti menggunakan teknik tes, wawancara, dan dokumentasi. Triangulasi subjek dilakukan dengan memeriksa kesesuaian data dari berbagai sumber, yaitu dari siswa dan guru.

Pembelajaran model ProjectBased Learning (PjBL) menggunakan pendekatan Science, Technology, Engineering, and Mathematics (STEM). dilaksanakan dalam lima langkah pembelajaran yaitu reflection, research, discovery, application, dan communication. Implementasi pembelajaran $\mathrm{PjBL}$ menggunakan pendekatan STEM dilakukan secara embedded, yaitu pendekatan tertanam yang mengintegrasikan 2 atau 3 dari bidang STEM dimana terdapat satu bidang yang menjadi fokus utama penilaian sedangkan bidang lainnya 
DOI: https://doi.org/10.24127/ajpm.v10i1.3179

berperan sebagai pendukung pembelajaran (Winarni, Zubaidah, \& $\mathrm{H}$, 2016). Penelitian ini melibatkan aspek Science, Technology, dan Mathematics dimana bidang utama yang dikembangkan adalah Mathematics sedangkan Science dan Technology berperan sebagai pendukung konteks pembelajaran. Siswa menyelesaikan permasalahan matematis melalui soalsoal yang diberikan dan mengimplementasikannya dalam menyusun rancangan proyek secara berkelompok.

Peningkatan kemampuan komunikasi matematika siswa dalam penelitian ini dideskripsikan berdasarkan tiga indikator, yaitu: 1) menghubungkan ide matematika dengan gambar maupun representasi matematis tertentu, 2) menggunakan gambar, notasi, maupun simbol matematika dalam menyampaikan ide matematis dan 3) menggunakan bahasa matematika untuk menyelesaikan permasalahan matematis.

\section{HASIL DAN PEMBAHASAN}

Kemampuan komunikasi matematika siswa sebelum pemberian pembelajaran model PjBL menggunakan STEM dapat dikatakan rendah. Siswa tidak menggunakan notasi/simbol matematika dengan tepat terkait hasil perhitungan volume kubus. Bahasa dan representasi matematika yang digunakan juga sulit untuk dipahami. Siswa belum mampu mengidentifikasi dan menguraikan strategi penyelesaian masalah dengan baik sehingga jawaban yang diberikan tidak efektif. Hal ini terlihat dari jawaban siswa pada soal menghitung luas permukaan kubus dan balok pada Gambar 1.

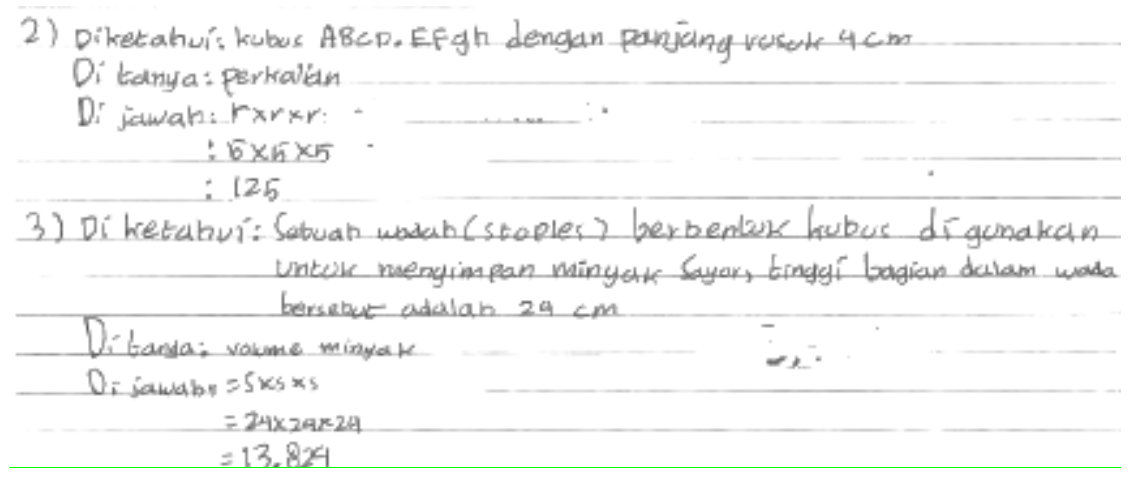

Gambar 1. Hasil jawaban siswa sebelum dilaksanakan pembelajaran model PjBL menggunakan pendekatan STEM

Gambar 1 adalah salah satu hasil tes awal kemampuan komunikasi matematika siswa sebelum pelaksanaan pembelajaran model PjBL menggunakan pendekatan STEM. Hasil tes awal kemampuan komunikasi matematika siswa pada 32 orang partisipan menunjukkan bahwa sebagian besar siswa belum mampu menghubungkan ide matematika dengan gambar maupun representasi matematis tertentu, sehingga berdampak bagi rendahnya kemampuan menyelesaikan masalah matematika dengan representasi yang tepat. Berdasarkan Gambar 1, terjadi kekeliruan siswa dalam menggunakan prosedur matematis. Siswa memahami konteks soal nomor 2 sebagai perhitungan volume, bukan sebagai perhitungan luas permukaan bangun. 
DOI: https://doi.org/10.24127/ajpm.v10i1.3179

Konfirmasi dilakukan melalui wawancara terhadap 5 orang siswa, berdasarkan hasil wawancara bahwa siswa S03 mengaku tidak dapat menggambarkan kembali perubahan ukuran panjang bangun karena hal itu sangat sulit. Siswa S01, S02, S04, dan S05 mengaku kesulitan untuk menggunakan rumus yang tepat. Dari hasil wawancara tersebut, diketahui bahwa siswa masih terpaku untuk mengingat rumus dan belum mampu menghubungkan ide matematis dalam gambar yang disajikan sehingga kesulitan untuk menjelaskannya kembali. Hal ini juga dibuktikan dengan tidak adanya siswa yang mencapai Kriteria Ketuntasan Minimal (KKM) yaitu 65 dalam hasil tes awal kemampuan komunikasi matematika sebelum implementasi pembelajaran PjBL menggunakan pendekatan STEM.

Hasil wawancara dengan guru kelas bahwa selama ini siswa terpaku untuk mengingat rumus namun minim dalam memahami konsep dasar, sehingga sering terjadi kesalahan dalam menguraikan jawaban, terlebih jika diminta untuk menggambarkannya ke dalam ilustrasi matematis yang relevan akan sangat sulit bagi siswa. Masalah tersebut sejalan dengan yang telah dikemukakan oleh Liestarie \& Karlimah (2017) bahwa kemampuan siswa dalam menulis matematis dan memahami ide dalam konteks tertentu masih rendah. Ketika siswa mampu memahami suatu permaslahan dalam konteks tertentu maka siswa tidak terpaku pada formula/rumus. Dengan pemahaman yang sudah ada, siswa akan bernalar untuk mencari solusi permasalahan lalu menyampaikannya kembali dalam bahasa matematis yang tepat.
Pembelajaran PjBL terintegrasi STEM mulai dilakukan setelah analisis kemampuan awal siswa dalam komunikasi matematika. Kegiatan pembelajaran dilaksanakan sebanyak tiga kali pembelajaran tatap muka di sekolah dan dua kali kegiatan belajar dari rumah. Kegiatan pembelajaran dan pelaksanaan proyek dilaksanakan simultan, namun karena pandemi Covid-19 sehingga siswa melakukan aplikasi konsep volume kubus dan balok melalui kegiatan pembuatan proyek Peti Sejuk secara daring selama masa belajar dari rumah.

Kemampuan komunikasi matematika siswa dilatih melalui kegiatan belajar kooperatif setiap kelompok terdiri dari 4 orang siswa. Pembelajaran secara berkelompok dilakukan guna mengasah kemampuan komunikasi matematika melalui diskusi untuk menyelesaikan masalah bersamasama anggota kelompoknya (Alhaddad, Kusumah, Sabandar, \& Dahlan, 2015) Setiap kelompok menyelesaikan permasalahan matematika yang disajikan dalam Lembar Kerja Siswa dan menyusun rancangan proyek dalam Lembar Pelaksanaan Proyek. Langkah pertama dalam sintaksis pembelajaran PjBL-STEM adalah reflection. Beberapa materi yang termuat dalam LKS siswa adalah 1) sifat dan unsur balok dan kubus, 2) jaring-jaring dan luas permukaan balok dan kubus, 3) volume balok dan kubus, 4) pangkat tiga, akar pangkat tiga dan akar pangkat tiga menggunakan konsep volume kubus, 5) menyelesaikan masalah terkait volume balok dan kubus. Salah satu hasil pekerjaan siswa pada tahap reflection dapat dilihat pada Gambar 2 . 
DOI: https://doi.org/10.24127/ajpm.v10i1.3179

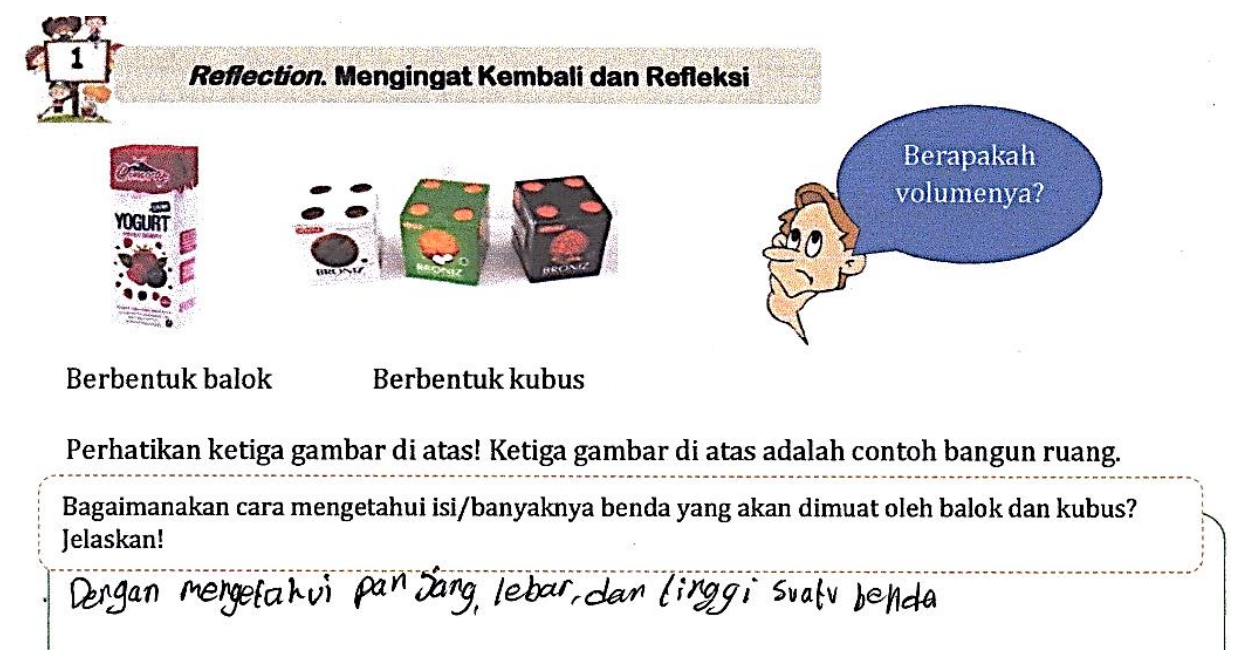

Gambar 2 Hasil pekerjaan kelompok siswa tahap reflection

Dari Gambar 2 terlihat bahwa siswa mampu mengumpulkan informasi terkait materi yang dibahas kemudian menjelaskannya kembali secara tertulis menggunakan representasi yang tepat. Kegiatan reflection dalam Lembar Proyek Siswa (LPS) berisi kegiatan menghubungkan konsep bangun ruang balok dan kubus dengan konteks kehidupan nyata. Setelah melalui tahap reflection, tahap berikutnya adalah research yang berupa kegiatan menemukan infromasi. Tahap research pada LKS adalah siswa mencoba menemukan sendiri informasi terkait materi. Siswa mencari informasi melalui buku, blog, youtube, dan ensiklopedia. Kegiatan research dalam LPS siswa adalah berupa kegiatan mencari informasi untuk menyusun proyek guna mengaplikasikan konsep volume kubus dan balok. Dalam hal ini, siswa memilih kegiatan proyek membuat kulkas sederhana dengan memanfaat bak kedap air dan pasir basah yang diberi nama Peti Sejuk. Pemilihan proyek tersebut sebagai latihan mengaplikasikan konsep matematika untuk menyelesaikan permasalahan sehari-hari.

Hasil pekerjaan salah satu kelompok siswa pada tahap research adalah sebagaimana Gambar 3.

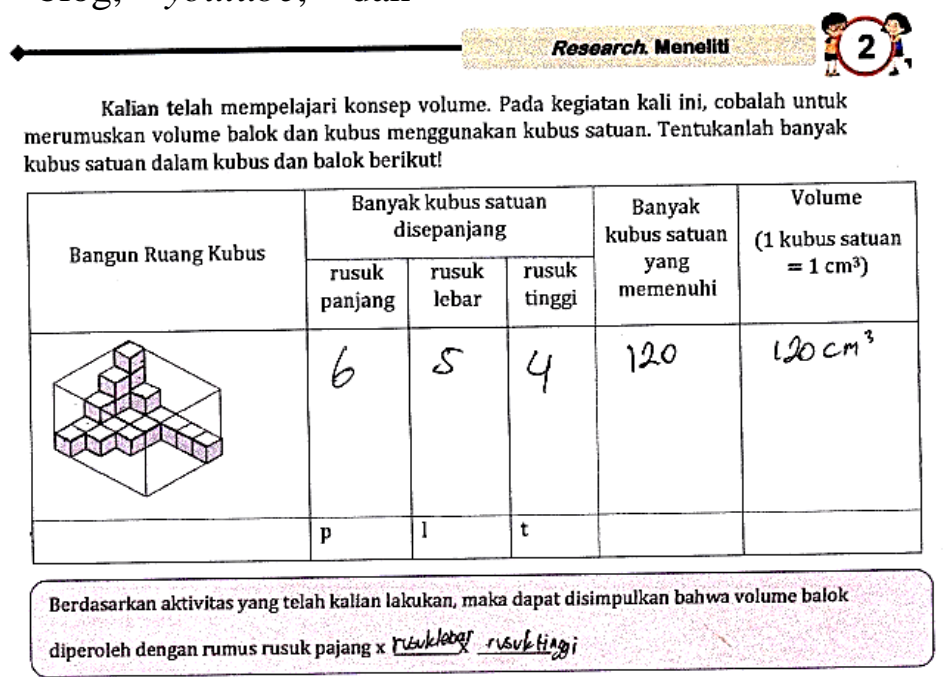

Gambar 3. Hasil pekerjaan kelompok siswa tahap research 
DOI: https://doi.org/10.24127/ajpm.v10i1.3179

\begin{abstract}
Pada Gambar 3 tampak bahwa siswa melakukan konstruksi pemahaman dalam rangka menentukan rumus mencari volume balok. Bahan manipulatif dihadirkan dalam pembelajaran guna membantu siswa memahami konsep volume kubus. Bahan manipulatif dalam pembelajaran matematika berperan dalam menyederhanakan konsep, mengkonkritkan konsep matematika yang abstrak, dan melatih keaktifan siswa (Hastuti \& Sutarto, 2018). Penggunaan bahan manipulatif dalam pembelajaran matematika mampu meningkatkan capaian belajar matematika siswa (Kusuma, Shodiqin, \& Listyarini,
\end{abstract} 2018). Bahan manipulatif yang digunakan dalam pembelajaran ini berupa puzzle jaring-jaring balok dan kubus dan replika balok dan kubus berisi kubus satuan yang dapat dibongkar pasang oleh siswa.

Bantuan bahan manipulatif dalam pembelajaran ini bertujuan agar siswa dapat memahami konsep luas permukaan balok dan kubus melalui puzzle jaring-jaring balok dan kubus dan konsep volume balok dan kubus. Siswa aktif menyentuh dengan tangan, mencoba, membuktikan menyusun ulang, dan melakukan perbaikan. Dalam proses pembelajaran, siswa menggunakan bahan manipulatif secara aktif dalam memahami sifat dan unsur balok maupun kubus, menyusun definisi balok dan kubus, mereka membuktikan pola jaring-jaring kubus, dan menentukan volume balok dan kubus kemudian hasilnya diuraikan dalam LKS. Kegiatan yang demikian adalah untuk melatih siswa untuk memiliki dua indikator kemampuan komunikasi matematika, yaitu 1) menghubungkan ide matematika dengan gambar maupun representasi matematis tertentu, 2) menggunakan gambar, notasi, maupun simbol matematika dalam menyampaikan ide matematis. Berdasarkan Gambar 3, tampak bahwa siswa telah mampu menguhubungkan ide matematika dalam perintah soal lalu membuktikannya dengan bahan manipulatif yang tersedia, hasil dari proses tersebut siswa dapat menggunakan angka dan simbol mtematika dalam menyampaikan ide matematis.

Kondisi ini tidak hanya tampak pada fase reflection dan research tetapi juga pada tahap discovery. Dalam LKS, tahap discovery berisi aktivitas menemukan informasi-informasi penunjang dalam memahami materi matematika, dalam penyelesaian proyeknya siswa melakukan tahap discovery untuk menghimpun informasi yang lebih detail sehingga mereka mampu membuat konstruksi prototype proyek. Salah satu hasil pekerjaan salah satu kelompok siswa pada tahap discovery yang tertulis dalam LPS adalah seperti yang tercantum pada Gambar 4a dan Gambar 4b.

Berdasarkan Gambar 4a dan Gambar 4b tampak bahwa siswa menyampaikan ide pembuatan Peti Sejuk dengan menggunakan representasi matematis yang relevan. Siswa merancang alat dan bahan yang dibutuhkan, melakukan estimasi ukuran panjang dan volume, mengkonstruksi gambar, dan menemukan informasi tambahan mengenai kelebihan dan kekurangan Peti Sejuk yang akan dibuat. Hal selanjutnya yang dilakukan adalah mengkonfirmasi hasil pekerjaan siswa terhadap siswa atau kelompok siswa yang bersangkutan. Hal ini dilakukan untuk memperoleh informasi yang mendalam dan lengkap, sehingga dapat diperoleh hasil yang maksimal. 
AKSIOMA: Jurnal Program Studi Pendidikan Matematika

DOI: https://doi.org/10.24127/ajpm.v10i1.3179

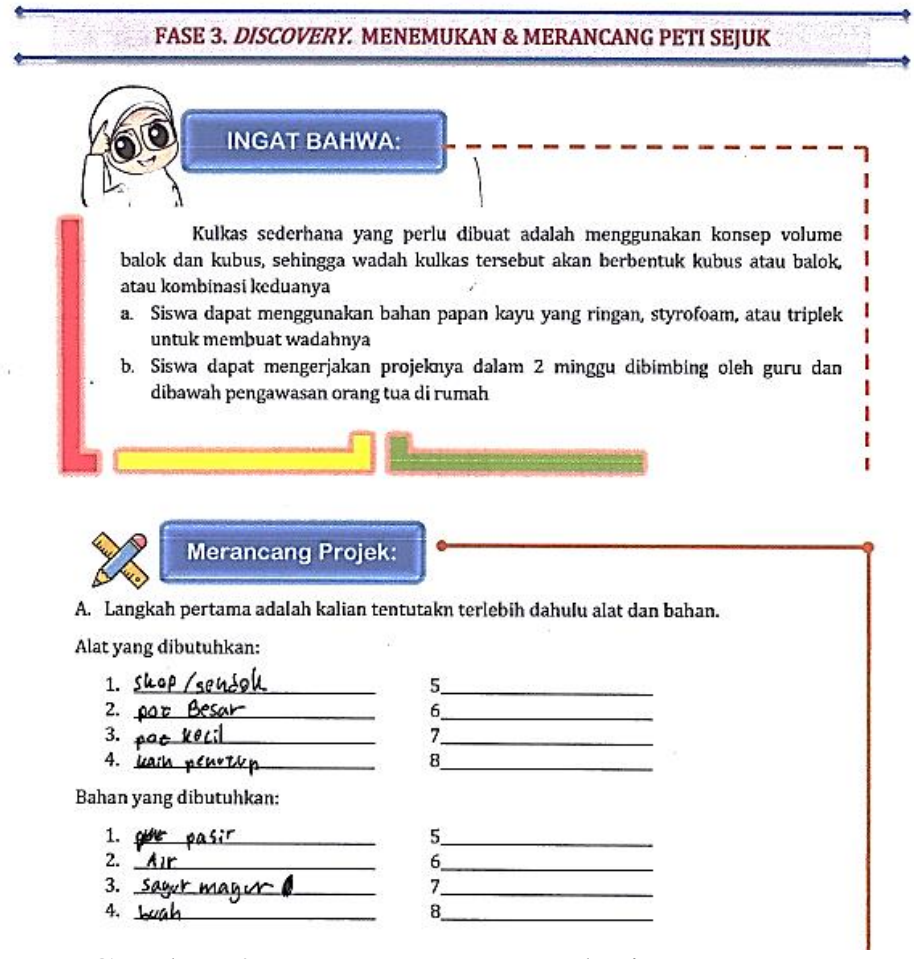

Gambar 4a. Rancangan proyek siswa

B. Tentukanlah volume wadah yang akan kalian buat

\begin{tabular}{|l|c|c|}
\hline \multicolumn{1}{|c|}{ Wadah } & $\begin{array}{c}\text { Bentuk } \\
\text { (Kubus/balok) }\end{array}$ & Ukuran \\
\hline $\begin{array}{l}\text { Wadah 1 } \\
\text { (wadah bagian luar) }\end{array}$ & Bolok Besar & $3 \mathrm{~g} . \mathrm{cm} \times .20 . \mathrm{cm} \times 15 . \mathrm{cm}$ \\
\hline $\begin{array}{l}\text { Wadah 2 } \\
\text { (wadah bagian dalam) }\end{array}$ & Balak kect) & $2 \mathrm{~g} . \mathrm{cm} \times .6 . \mathrm{cm} \times 10 \mathrm{~cm}$ \\
\hline
\end{tabular}

C. Gambarlan model wadah rancangan kalian, berikan keterangan struktur alat tersebut

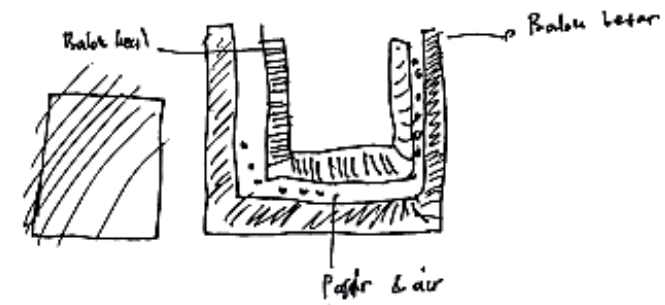

\footnotetext{
D. Kelebihan dan kekurangan alat yang kalian rancang

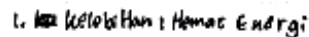

idapat dilakukan di rumats

:Bahan Mudah didafat

2. kelurangan: tidak bisa mem be kukan air

itempatinya terbatas

i wakernya hama
}

Gambar 4b. Rancangan proyek siswa 
DOI: https://doi.org/10.24127/ajpm.v10i1.3179

Hasil konfirmasi terhadap siswa diperoleh hasil, yaitu siswa S04 menjelaskan bahwa kelompok mereka merancang prototipe yang akan terbuat dari sterofoam, mereka terinspirasi dari box penampung ikan para penjual ikan di pasar. Namun, pada kelompok lain S05 mengakui bahwa Peti Sejuk rancangan mereka akan menggunakan papan triplek tebal yang dilengkapi dengan tutup, sehingga pasir basah tetap sejuk di dalam kotak triplek tersebut. Siswa S01 justru meniru pedagang ikan di pasar, mereka merancang Peti Sejuk berisi pasir basah yang ditambahkan bongkahan es batu di dalamya, alasannya adalah agar suhu di dalam kotak/wadah tetap lebih rendah daripada suhu di ruang terbuka.

Berdasarkan hasil pekerjaan siswa pada fase reflection, research dan discovery serta hasil konfirmasi tersebut menunjukkan bahwa siswa telah mampu menjelaskan ide dalam menyelesaikan masalah yang disertai dengan alasan yang logis. Pada fase application, siswa mencoba mengaplikasikan konsep materi volume balok dan kubus yang telah pelajari dalam menyelesaikan masalah. Siswa menyelesaikan soal-soal penyelesaian masalah kemudian hasilnya diuraikan dalam LKS. kemudian fase application secara praktis adalah siswa membuat prototipe Peti Sejuk sesuai dengan rancangannya. Temuan ini sejalan dengan pendapat Tati, Firman, \& Khoiri $(2017,6)$ konteks sains dan teknologi dalam pembelajaran PjBL terintegrasi STEM memberi kesempatan bagi siswa untuk bereksplorasi dan melakukan percobaan, sehingga dari kegiatan tersebut siswa terlatih untuk membuat perencanaan, melakukan estimasi, melakukan pengukuran, dan mengomunikasikan hasil dengan bahasa yang komunikatif.

Pendapat Robert \& Cantu (2012)

bahwa dalam pembelajaran PjBL terintegrasi STEM siswa kelas 5 sekolah dasar perlu mencapai kemampuan matematis berupa melakukan estimasi dan pengukuran dari rancangan prototipe dalam proyek yang dilakukan. Hasil rancangan proyek menunjukkan bahwa siswa telah mampu mengomunikasikan ide dan strategi penyelesaian menggunakan bahasa matematika yang relevan. Fase commucication juga dilakukan dengan baik oleh siswa dalam setiap pembelajaran. Siswa mempresentasikan hasil penyelesaian masalah berdasarkan soal dalam LKS, terjadi diskusi dan tanya jawab antar siswa dan guru. Selain itu, siswa juga sudah dapat menjelaskan proyek kelompoknya masing-masing kepada guru.

Tes akhir diberikan setelah implementasi pembelajaran guna mengetahui perkembangan kemampuan komunikasi matematika siswa. Gambar 5 adalah salah satu contoh hasil pekerjaan siswa dalam tes akhir kemampuan komunikasi matematika pada aspek menghubungkan ide matematika dengan gambar maupun representasi matematis tertentu.

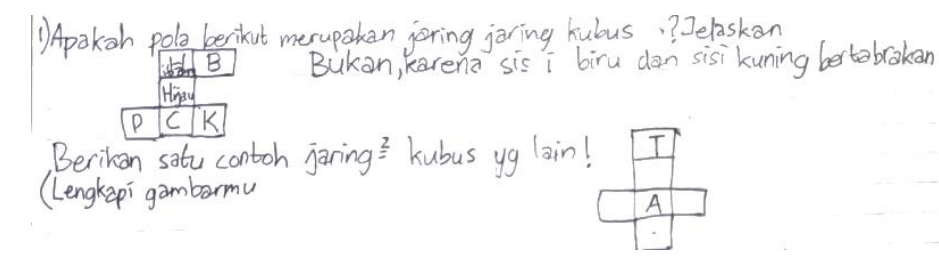

Gambar 5. Hasil pekerjaan siswa dalam menghubungkan ide matematika dengan gambar maupun representasi matematis tertentu 
DOI: https://doi.org/10.24127/ajpm.v10i1.3179

$\begin{array}{cc}\text { Berdasarkan } & \text { Gambar 5, terlihat } \\ \text { bahwa siswa } & \text { sudah mampu }\end{array}$ menghubungkan ide matematis berdasarkan gambar dengan pengetahuan yang telah ia susun terkait jaring-jaring kubus, sehingga siswa dapat menyimpulkan bahwa gambar jaringjaring kubus yang disajikan dalam soal tidak memberikan contoh jaring-jaring kubus yang tepat. Kemampuan untuk menghubungkan ide matematika dengan berbagai representasi matematis perlu didasari oleh pemahaman yang mendalam, menurut Ralph (2015) proyek yang diberikan kepada siswa memberi kesempatan untuk in-dept inquiry atau membangun pemahaman mendalam. Dalam proses memahami dan membangun konsep secara mendalam, siswa melakukan berbagai usaha seperti membaca buku dan mengakses informasi melalui internet maupun youtube di bawah bimbingan guru dan orang tua.

Kemampuan menghubungkan ide matematika dengan berbagai representasi matematis juga berkaitan dengan kemampuan siswa untuk menggunakan berbagai representasi matematis baik berupa angka, gambar, maupun metode aljabar untuk menyampaikan ide matematis yang dipahaminya. Kemampuan siswa dalam menggunakan gambar, notasi, maupun simbol matematika dapat dilihat pada Gambar 6.

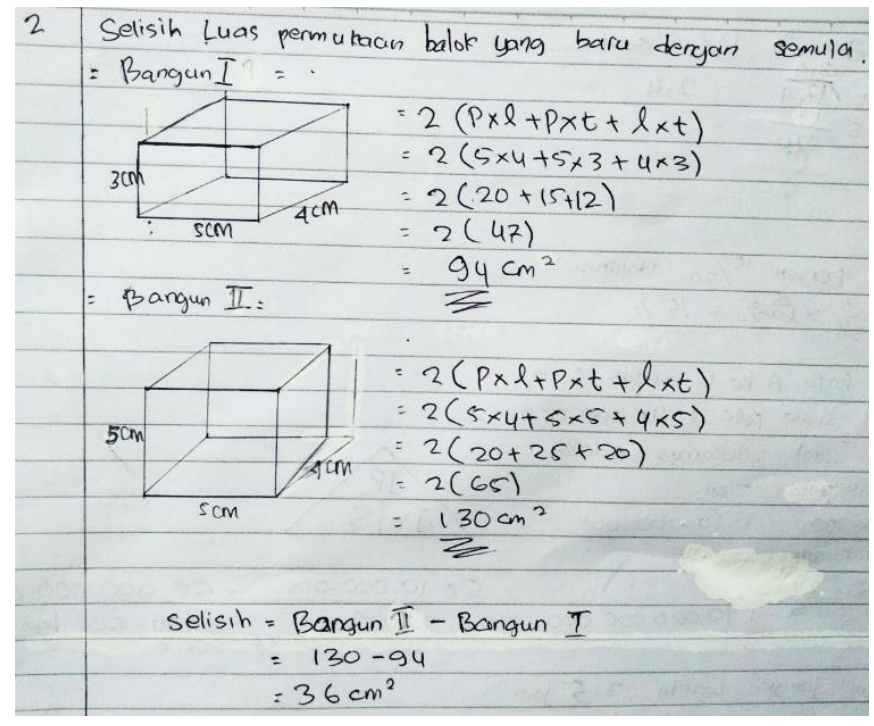

Gambar 6. Hasil pekerjaan siswa dalam menggunakan gambar, notasi, maupun simbol matematika untuk menyampaikan ide matematis

Berdasarkan hasil tes akhir kemampuan siswa, salah satunya pada Gambar 6 terlihat bahwa siswa sudah mampu memahami ide matematis dalam gambar kemudian menghubungkannya dengan pemahaman yang sudah mereka konstruksi selama proses pembelajaran, sehingga siswa dapat menyelesaikan perhitungan perubahan luas permukaan balok dan kubus sebagai akibat dari perubahan ukuran rusuk. Sebagian besar siswa sudah mampu mengidentifikasi masalah dalam soal, menyusun solusi permasalahnnya, dan menguraikan jawabannya secara matematis.

Hasil tes setelah pemberian pembelajaran PJBL terintegrasi STEM bahwa sebanyak $78,125 \%$ siswa telah 
DOI: https://doi.org/10.24127/ajpm.v10i1.3179

mencapai skor diatas KKM 65. Berdasarkan analisis pada setiap indikator kemampuan komunikasi matematika, diketahui bahwa ketercapaian indikator ke-3 belum sampai $75 \%$, berbeda dengan indikator ke-1 dan indikator ke-2 yang sudah melebihi $75 \%$. Meskipun belum semua indikator kemampuan komunikasi matematika mencapai $75 \%$, namun terdapat peningkatan nilai rata-rata capaian siswa pada setiap indiator tersebut. Pada Gambar 7 dapat dilihat peningkatan kemampuan komunikais matematika siswa setiap indikator.

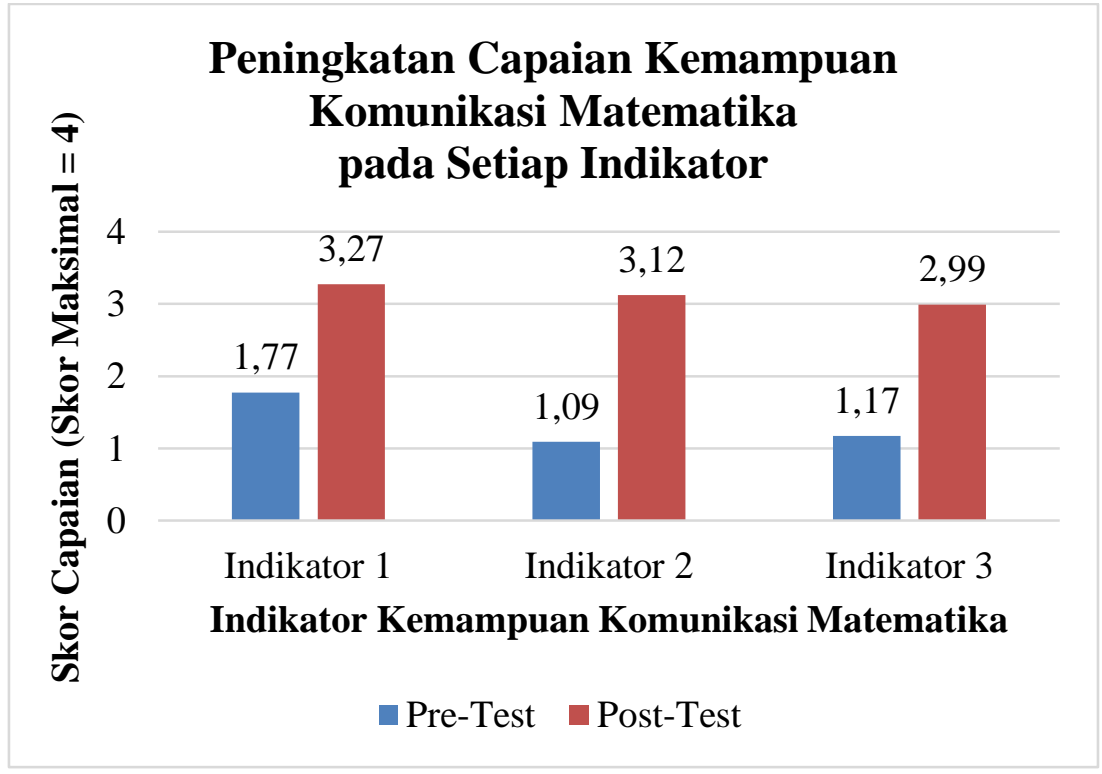

Gambar 7. Grafik peningkatan capaian kemampuan komunikasi matematika pada setiap indikator

Indikator pertama yaitu menjelaskan ide matematika (sifat atau konsep) yang sesuai dengan gambar, notasi, simbol atau representasi matematika tertentu, kenaikan capaian siswa pada indikator ini hanya sebesar 37,5\%. Meski peningkatan tidak mencapai $50 \%$, tetapi capaian siswa pada post-test kemampuan komunikasi matematika untuk indikator ini sudah melebihi $75 \%$ yaitu $81,72 \%$. Hal serupa juga berlaku bagi peningkatan kemampuan komunikasi matematika siswa pada indikator kedua yaitu menjelaskan ide matematika (sifat atau konsep) ke dalam bentuk gambar, notasi, simbol atau representasi matematika lainnya. Peningkatan pada indikator kemampuan komunikasi matematika yang kedua dari sebelum dan sesudah pemberian perlakuan adalah sebesar 50,63\%. Hasil tes akhir setelah pemberian perlakuan adalah terjadi peningkatan kemampuan komunikasi matematika siswa mencapai $77,97 \%$. Persentase capaian indikator kedua ini sudah melampaui $75 \%$.

Capaian

kemampuan komunikasi matematika siswa pada indikator menyelesaikan masalah dengan menggunakan konsep, strategi dan representasi matematika yang sesuai secara lengkap dan runtut adalah sebesar $74,81 \%$. Berdasarkan analisis hasil tes sebelum dan sesudah implementasi pembelajaran hanya terjadi peningkatan sebesar $45,51 \%$ pada inikator tersebut. 
DOI: https://doi.org/10.24127/ajpm.v10i1.3179

Dari ketiga indikator kemampuan komunikasi matematika yang diteliti, hanya indikator menggunakan gambar, notasi, maupun simbol matematika dalam menyampaikan ide matematis yang mengalami peningkatan lebih dari 50\% sedangkan peningkatan dua indikator lainnya belum mencapai $50 \%$. Berdasarkan hasil analisis indikator tersebut dipahami bahwa masih terdapat siswa yang belum mampu menghubungkan ide matematika dengan gambar maupun representasi matematis tertentu dan masih terdapat siswa yang belum mampu menggunakan bahasa matematika untuk menyelesaikan permasalahan matematis.

Hasil wawancara menunjukkan bahwa 2 dari 5 orang siswa yang diwawancara mengaku sulit menghubungkan konteks masalah dalam soal dengan ide matematis terlebih jika soal tersebut berupa gambar geometri. Hasil analisis dokumen pekerjaan siswa dalam menyelesaikan soal tes kemampuan komunikasi matematika diketahui bahwa masih terdapat siswa yang melakukan kesalahan menulis lambang satuan volume, kesalahan dalam menyusun jaring-jaring balok/kubus, dan masih ada beberapa siswa yang belum mampu menjelaskan ide matematis ke dalam representasi matematis berupa gambar. Temuan penelitian tersebut sejalan dengan pendapat Noviarny, Murtono, \& Ulya, (2018) bahwa aspek kemampuan komunikasi matematika yang sering kali salah dilakukan oleh siswa adalah menulis matematika.

Hasil wawancara 4 dari 5 orang siswa mengaku bahwa mereka masih kesulitan dalam menyelesaikan masalah matematika secara runtut, siswa terbiasa menuliskan rumus saja dengan hasil jawaban singkat, dan masih terdapat siswa yang tidak mampu memberikan kesimpulan penyelesaian masalah. Temuan ini sejalan dengan Ariani (2017, 98) dan Liestarie \& Karlimah (2017, 111) bahwa kesulitan siswa dalam penyelesaian masalah matematis adalah karena rendahnya kemampuan menulis gagasan matematis.

Kesalahan menulis matematika yang dilakukan oleh siswa dapat terjadi karena beberapa faktor lain yang juga berpengaruh, seperti siswa belum menguasai kemampuan awal dengan baik. Dengan demikian, dirasa perlu untuk menyiapkan kemampuan awal matematika siswa dengan baik, terutama dalam mengenal dan menggunaakan simbol/lambang matematika dengan benar. Selain itu, juga perlu untuk membiasakan siswa menyelesaikan soal-soal matematika untuk melatih penggunaan kosa kata matematika dengan tepat.

Kesalahan dalam menulis matematika yang dijelaskan di atas hanya terjadi pada sebagian siswa, karena sebagian besar siswa telah mampu mengemukakan ide matematis (sifat/konsep) ke dalam representasi gambar, angka, maupun aljabar. Hal ini dibuktikan dengan capaian kemampuan komunikasi matematika siswa dalam tiga indikator yang diteliti mengalami peningkatan setelah implementasi pembelajaran, dimana peningkatan tertinggi adalah pada indikator menggunakan gambar, notasi, maupun simbol matematika dalam menyampaikan ide.

Berdasarkan analisis dokumen hasil LKS dan LPS siswa diketahui bahwa siswa dapat menulis ide matematis menggunakan gambar, notasi, maupun simbol matematika maka dapat dikatakan bahwa pembelajaran PjBL-STEM yang 
diimplementasikan tersebut dapat melatih dan mengembangkan kemampuan komunikasi matematika siswa. Hasil temuan penelitian sejalan dengan pendapat Chalim, Mariani, \& Wijayanti (2019) bahwa pembelajaran proyek menggunakan STEM dapat meningkatkan kemampuan komunikasi matematika siswa. peningkatan kemampuan komunkasi matematika siswa sekolah dasar yang diberi pembelajaran proyek berbasis STEM adalah dalam aspek menyampaikan ide melalui kosa kata matematis seperti menyatakan panjang, luas, variabel, teorema, dan bahasa matematika lainnya (Bicer, Boedeker, Capraro, \& Capraro, 2015). Adanya efek positif dari pembelajaran tersebut menurut Ambarwati, Dwijanto, \& Hendikawati (2015) karena penggunaan konteks real yang dikemas dalam aktivitas belajar berbasis proyek, sehingaa siswa belajar dalam situasi yang lebih konkret dan bermakna.

Implikasi penelitian ini menunjukkan masih adanya siswa yang melakukan kesalahan dalam melakukan interpretasi ide matematis. Hal ini ditunjukkan dari kesalahan siswa menyelesaikan masalah dalam soal. Guru dapat melakukan upaya membantu siswa membangun pemahaman awal yang baik, membiasakan siswa untuk mengemukakan pemahaman berdasarkan masalah melalui bahasa lisan agar guru dapat mendeteksi lebih awal kesalahan intepretasi matematis yang dilakukan siswa, dan meningkatkan kuantitas dan kualitas soal penyelesaian masalah yang disajikan kepada siswa,

\section{KESIMPULAN DAN SARAN}

Kesimpulan yang diperoleh dari penerapan pembelajaran Project-Based Learning terintegrasi STEM bahwa terjadi peningkatan kemampuan komunikasi matematika siswa dalam tiga aspek yang diteliti, yaitu menghubungkan ide matematis berdasarkan gambar maupun representasi matematika yang relevan, menggunakan gambar maupun representasi matematis yang sesuai untuk menyampaikan ide matematis, dan menggunakan bahasa matematika untuk menyelesaikan permasalahan matematis. Selain itu, sebanyak $78,125 \%$ siswa termasuk dalam ketegori tuntas berdasarkan KKM yang digunakan pada kelas penelitian.

Berdasarkan hasil penelitian, dapat disampaikan saran untuk mengembangkan penelitian serupa: (1) hendaknya memastikan setiap siswa memiliki kemampuan awal yang baik dalam melakukan operasi hitung perkalian dan pembagian agar memudahkan siswa dalam menghitung hasil pengukuran dan melakukan estimasi produk yang dibuat, sehingga tidak menghambat proses penyusunan rancangan proyek, (2) hendaknya memastikan siswa mampu menggambar benda dengan representasi yang realistis agar memudahkan proses analisis kemampuan komunikasi matematika siswa, (3) hendaknya konteks proyek yang digunakan dapat lebih inovatif agar produk yang dihasilkan oleh siswa lebih bervariasi dan pengalaman belajar yang diperoleh siswa juga lebih beragam .

\section{DAFTAR PUSTAKA}

Aguilar, N. A. (2016). Examining the integration of Science, Technology, Engineering, and Mathematics (STEM) in preschool and transitional kindergarten (TK) classrooms using a social-constructivist approach. ProQuest Dissertations and Theses, 107. 
Alhaddad, I., Kusumah, Y. S., Sabandar, J., Dahlan, J. A. (2015). Enhancing students' communication skills through treffinger teaching model. IndoMS-JM, 6(1), 31-39.

Ambarwati, R., Dwijanto, \& Hendikawati, P. (2015). Keefektivan Model ProjectBased Learning Berbasis GQM terhadap Kemampuan Komunikasi Matematis danPercaya Diri Siswa Kelas VII. Unnes Journal of Mathematics Education, 4(2) 180-186.

Ariani, D. N. (2017). Strategi Peningkatan Kemampun Komunikasi Matematis Siswa SD/MI. Muallimuna: Jurnal Madrasah Ibtidaiyah, 3(1), 96107.

Bicer, A., Boedeker, P., Capraro, R.M., \& Capraro, M. M. (2015). The Effect of STEM PBL on Students' Mathematical and Scientific Vocabulary Knowledge. International Journal of Contemporary Educational Research (IJCER), 2(2), 69-75.

Chalim, M. N., Mariani, S., \& Wijayanti, K. (2019). Kemampuan Komunikasi Matematis Siswa SMK Ditinjau dari Self Efficacy pada Setting Pembelajaran Project Based Learning Terintegrasi STEM. In PRISMA Prosiding Seminar Nasional Matematika (pp540550). Semarang: Universitas Negeri Semarang.

Daugherty, M. K., Carter, V., \& Swagerty, L. (2014). Elementary STEM education: The future for Technology and Engineering education? Journal of STEM Teacher Education, 49(1), 4555.

Hastuti, I. D., \& Sutarto. (2018). Bahan Manipulatif dalam Pembelajaran Matematika Sekolah Dasar. Mataram: LPP Mandala.

Kongthip, Y., Inprasitha, M., Pattanajak, A., \& Inprasitha , N. (2012). Mathematical communication by 5th grade students' gestures in lesson study and open approach context. Scientific Research, 3(8), 632-637.

Kleden, M. A., Kusumah, Y. S., \& Sumarmo, U. (2015). Analysis of enhancement of mathematical communication competency upon students of Mathematics education study program through metacognitive learning. International Journal of Education and Research, 3(9). 349-358.

Kosko, K. W., \& Wilkins, J. L. M. (2010). Mathematical communication and its relation to the frequency of manipulative use. International Electronic Journal of Mathematics Education-I $J J M \Sigma$. 5(2), 81-90.

Kusuma, I. R., Shodiqin, A., \& Listyarini, I. (2018). Keefektivan Model Pembelajaran Kooperatif Tipe TS-TS dan CTL Berbantu Media Bnda Manipulatif Terhadap Hasil Belajar Matematika Siswa Kelas V. Jurnal Sekolah, 2(3), 192-198.

Laboy-Rush, D. (2010). Integrated STEM education through Project-Based Learning. (Research Report) Retrieved from Learning.com 
DOI: https://doi.org/10.24127/ajpm.v10i1.3179

http://rondoutmar.sharpschool.co $\mathrm{m} /$ UserFiles/Servers/Server_719 363/File/12-13/STEM/STEMWhite-Paper 101207 final[1].pdf Liestarie, R. R., \& Karlimah. (2017). Analsisi kemampuan komunikasi matematis siswa kelas III sekolah dasar pada materi mengenal konsep pecahan. Pedakdiktika: Jurnal Ilmiah Pendidikan Guru Sekolah Dasar. 4(1), 109-119.

Miles, M. B., Huberman, A. M., \& Saldaña, J. (2014). Qualitative data analysis: A methods sourcebook (3rd edition). Los Angeles: SAGE Publications, Inc.

Moyer, P. S. (2000). Communicating mathematically: Children's literature as a natural connection. The Reading Teacher, 54(3), 246-255.

Nesri, F. D. P., \& Kristanto, Y. D. (2020). Pengembangan Modeul Ajar Berbantuan Teknologi untuk Mengembangkan Kecakapan Abad 21 Siswa. Aksioma, 9(3),480-492.

NCTM. (2000). Executive Summary Principles and Standards for School Mathematics. (K. Beall, Ed.). United States of America.

Noviarny, D. A., Murtono, M., \& Ulya, H. (2018). Model think talk write berbantuan media monomat meningkatkan kemampuan komunikasi matematika siswa sekolah dasar. ANARGYA: Jurnal Ilmiah Pendidikan Matematika, 1(1), 21-28.

Purnamasari, S., \& Herman, T. (2016). Penggunaan Multimedia Interaktif Terhadap Peningkatan
Kemampuan Pemahaman dan Komunikasi Matematis, serta Kemadnrian Belajar SIswa Sekolah Dasar. Eduhumaniora: Jurnal Pendidikn Dasar. 8(2), 178-185

Ralph, R. A. (2012). Post Secondary Project-Based Learning in Science, Thechnology, Engineering, and Mathematics. Journal of Thechnology and Science Education (JOTSE), 6(1), 26-35.

Roberts, A., \& Cantu, D. (2012). Applying STEM instructional strategies to design and technology curriculum., The PATT 26 Conference (pp. 111118). Stockholm, Sweden: Linköpings Universitet.

Tati, T., Firman, H., \& Riandi, R. (2017). The Effect of STEM Learning through the Project of Designing Boat Model toward Student STEM Literacy. Journal of Physics: International Conference on Mathematics and Science Education (ICMScE), 012157.

Trilling, B., \& Fadel, C. (2009). 21st Century Skills: Learning for Life in Our Times. USA: Jossey-Bass

Valle, I., \& Barbosa, A. (2017). The Importance of Seing in Mathematics Communication. Journal of The European Teacher Education Network, 12(-), 49-63.

Walle, J. A. V, Karp, K. S., \& BayWilliams, J. M. (2010). Elementary and Middle School Mathematics: Teaching Developmentally (Eighth Edition). Upper Saddle River: Perason 
DOI: https://doi.org/10.24127/ajpm.v10i1.3179

Winarn Winarni, J., Zubaidah, S., \& H., S. K. (2016). STEM: Apa, Mengapa, dan Bagaimana. Prosseding Seminar Nasional Pendidikan IPA Pascasarjana UM. (pp. 976-984). Malang: Universitas Negeri Malang.

Yang, E. F. Y., Chang, B., Cheng, H. N. H., \& Chan, T. W. (2016). Improving pupils' mathematical communication abilities through computer-supported reciprocal peer tutoring. Journal of Educational Technology and Society, 19(3), 157-169.

Zetriuslita \& Jarnawi, W. (2018). Mathematical communication ability and curiosity attitude through Problem Based Learning and cognitive conflict strategy based on academic level: A study in number Theory. PEOPLE: International Journal of Social Sciences, 4(2), 726-742. 